\title{
PENGARUH PENAMBAHAN POLIETILEN GLIKOL 6000 PADA TABLET IBUPROFEN DISPERSI PADAT TERHADAP ABSORBSI IBUPROFEN SECARA IN SITU
}

\author{
Antetti Tampubolon \\ Jurusan Farmasi Poltekkes Kemenkes Medan \\ Email korespondensi : antettitampubolon.apt@gmail.com
}

\begin{abstract}
ABSTRAK
Penyerapan obat bisa diputuskan dengan berbagai metode, yaitu metode in vitro, metode in situ, dan metode in vivo. Metode in situ merupakan tata cara yang sangat dekat dengan tata cara in vivo. Tujuan dari riset ini merupakan buat mengenali pengaruh akumulasi polietilen glikol 6000 (PEG 6000) pada dispersi padat tablet ibuprofen terhadap absorpsi in-situ obat. Penelitian ini dilakukan melalui eksperimen untuk mengetahui pengaruh penambahan polietilen glikol 6000 terhadap absorbsi ibuprofen secara in situ dilakukan dengan mengalirkan larutan dari tablet ibuprofen dispersi padat, larutan dari tablet ibuprofen generik dan larutan ibuprofen baku. Sistem dispersi padat dilakukan dengan melebur ibuprofen dan polietilen glikol 6000 dengan perbandingan 1:05. Larutan obat dialiri melalui lumen usus halus tikus jantan. Ibuprofen yang tidak terserap diukur dengan spektrofotometer ultraviolet pada panjang gelombang 225, $5 \mathrm{~nm}$. Berikutnya dihitung kadar ibuprofen yang terabsorbsi. Hasil penelitian menunjukan ibuprofen dari sediaan tablet dispersi padat lebih banyak diabsorbsi dibandingkan ibuprofen dari tablet generik dan ibuprofen baku. Dapat disimpulkan polietilen glikol 6000 mempunyai pengaruh terhadap absorbsi ibuprofen secara in situ.
\end{abstract}

Kata kunci : Dispersi padat, Ibuprofen, in situ, PEG 6000 


\title{
THE EFFECT OF ADDITIONAL POLYETYLENE GLYCOL 6000 ON SOLID DISPERSION TABLETS IBUPROFEN ON IBUPROFENE ABSORBTION IN SITU
}

\begin{abstract}
Drug absorption can be decided by various methods, namely in vitro methods, in situ methods, and in vivo methods. The in situ method is a procedure that is very close to the in vivo method. The aim of this study was to identify the effect of accumulation of polyethylene glycol 6000 (PEG 6000) on solid dispersion of ibuprofen tablets on the insitu absorption of the drug. This research was conducted through an experiment to determine the effect of adding polyethylene glycol 6000 to the absorption of ibuprofen in situ by flowing the solution from solid dispersion ibuprofen tablets, solutions from generic ibuprofen tablets and standard ibuprofen solutions. The solid dispersion system was carried out by melting ibuprofen and polyethylene glycol 6000 in a ratio of 1:05. The drug solution was flowed through the lumen of the small intestine of male rats. Unabsorbed ibuprofen was measured by an ultraviolet spectrophotometer at a wavelength of $225.5 \mathrm{~nm}$. Next, the absorbed level of ibuprofen was calculated. The results showed that ibuprofen from solid dispersion tablets was absorbed more than ibuprofen from generic tablets and standard ibuprofen. It can be concluded that polyethylene glycol 6000 has an effect on the absorption of ibuprofen in situ.
\end{abstract}

Keywords : Solid dispersion, ibuprofen, in situ, PEG6000

\section{PENDAHULUAN}

Pemberian oral merupakan cara pengobatan yang sangat lumrah serta nyaman (Griffin, dkk., 2006). Bagi Ansel (1989) obat oral wajib menembus membran alat pencernaan usus (usus halus serta usus besar). Penyerapan obat lewat saluran cerna biasanya berlangsung melalui pelarutan pasif. Penyerapan obat dari usus halus senantiasa lebih cepat dari pada alat pencernaan, sebab permukaan epitel usus halus jauh lebih besar dari epitel alat pencernaan (Ganiswara, S, 2007).

https://doi.org/10.33759/jrki.v3i3.167 
Penyerapan obat bisa didefinisikan sebagai cara melewati obat dari tempat pemberian melalui penghalang biologis ke dalam aliran darah ataupun sistem limfatik. Absorbsi obat bisa didetetapkan dengan bermacam metode, ialah tata cara in vitro, in situ, serta in vivo. Absorbsi in situ lewat usus halus didasarkan pada determinasi laju kehilangan obat dari lumen usus. Meskipun hewan percobaan telah dibius dan dioperasi, suplai darah ke pusat, saraf, endokrin dan kelenjar getah bening masih utuh, sehingga mekanisme transportasi yang ditemukan dalam biologi masih efektif. Oleh karena itu, laju metode ini lebih realistis daripada hasil yang diperoleh dengan metode in vitro (Griffin dan Driscol, 2006).

Ibuprofen adalah bubuk kristal, putih hingga nyaris putih, dengan bau lemah yang khas. Ibuprofen hampir tidak larut dalam air, sangat larut dalam etanol, metanol, aseton serta kloroform, serta nyaris tidak larut dalam larutan etil asetat( Ditjen POM, 1995). Larut dalam air metal alkali hidroksida serta karbonat. Senyawa ini mempunyai titik cair $75-77^{\circ} \mathrm{C}$ dan $\mathrm{pKa}$ 4,4; 5,2 $\log$ P (oktanol/air) 4,0 (Moffat, dkk., 2005).

Ibuprofen termasuk dalam Model Compound Biopharmaceutical Classification System (BCS) II serta 213 mempunyai permeabilitas yang besar dan kelarutan yang kecil (Dahan serta Amidon, 2009). Buat obat dengan kelarutan rendah, pembubaran ialah langkah yang menentukan dalam proses penyerapan obat (Shargel serta $\mathrm{Yu}, 2005$; Leuner serta Dressman, 2000). Untuk mengatasi masalah ini, ibuprofen dibuat dengan sistem dispersi padat, dispersi padat dibentuk dalam pembawa yang dapat larut seperti PEG 6000. Sistem dispersi padat memakai ibuprofen selaku materi aktif yang efisien tidak larut dalam air, serta PEG 6000 selaku materi aktif. Pembawa inert, mudah larut dalam air. Hasil riset menunjukkan kalau sistem dispersi padat bisa tingkatkan kelarutan serta bioavailabilitas ibuprofen (Newa, dkk., 2008).

Berlandaskan penjelasan di atas, peneliti tertarik untuk mempelajari pengaruh penambahan polietilen glikol 6000 pada tablet dispersi padat terhadap absorbsi ibuprofen secara in situ

\section{METODE PENELITIAN}

Penelitian ini ialah riset eksperimen. Riset dimaksud guna memahami pengaruh penambahan polietilen glikol 6000 pada tablet ibuprofen dispersi padat terhadap absorbsi ibuprofen secara in situ.

https://doi.org/10.33759/jrki.v3i3.167 


\section{MATERIAL}

Alat yang dipakai pada riset ini ialah: timbangan analitik (vibrator), timbangan hewan, termometer, rangkaian alat infus, sleeve, tee, holder, wool, seperangkat alat bedah hewan, sarung tangan, stopwatch, water bath listrik, gelas ukur alat, pipet volumetrik, pipet maat, $\mathrm{pH}$ meter, termos dan alat gelas lainnya, spektrofotometer UV (Shimadzu mini, 1240).

Materi yang dipakai dalam riset ini adalah: ibuprofen (Hubei granulesBiocause Pharmaceutical, Co. Ltd), polietilen glikol 6000 (E. Merck), natrium dihidrogen fosfat pa (E. Merck), dinatrium hidrogen fosfat pa (E. Merck)., Potassium phosphate monobasic pa (E. Merck), Ketamin, Selulosa Mikrokristal, Magnesii Stearat, Talkum.

Pereaksi yang digunakan Air Bebas Carbondioxida, Dapar Fosfat pH 5,9 isotonis, Dapar Fosfat $\mathrm{pH} 7,2, \mathrm{NaCl}$ 0,9 \%, Natrium Hidroksida $0,1 \quad \mathrm{~N}$, Natrium Hidroksida 0,2 N.

Hewan percobaan ialah tikus wistar jantan dengan berat 250-300 gram. Sebelum percobaan, binatang diaklimatisasi di laboratorium selama kurang lebih satu pekan. Selama masa pemberian pakan, tikus diberi makan dan minum sesuai kebutuhan.

\section{Rancangan Penelitian}

\section{Pembuatan Dispersi Padat}

Dispersi padat adalah dispersi satu atau lebih bahan aktif dalam suatu pembawa inert yang mudah larut diantaranya: polietilen glikol, polivinilpirolidon, urea yang dibuat dengan metode peleburan, pelarutan. Dengan tujuan untuk memperkecil ukuran partikel, meningkatkan laju disolusi dan absorbsi obat yang tidak larut dalam air. Ibuprofen merupakan senyawa (obat) yang praktis tidak larut dalam air. Pembentukan dispersi padat antara ibuprofen dengan polietilen glikol 6000 dengan metode peleburan dapat meningkatkan kelarutan dan bioavailabilitas dari ibuprofen

Sistem dispersi padat terbuat dengan tata cara peleburan, serta perbandingan berat ibuprofen terhadap PEG 6000 merupakan 1: 0, 5. Setiap zat ditimbang secara proporsional dan dilebur di atas penangas air sembari diaduk. Lelehan dicampur, didinginkan serta dipadatkan dengan cepat dalam penangas es dengan pengadukan kuat, serta ditaruh dalam desikator sepanjang 24 jam setelah pemadatan. Padatan yang diperoleh dihaluskan serta lolos saringan 40 mesh. 
Pembuatan Tablet Ibuprofen Sistem

\section{Dispersi Padat}

Dispersi padat setara dengan 200

mg ibuprofen dibuat menjadi tablet. Tablet dibuat dengan pencetakan langsung menggunakan rumus berikut :

$\begin{array}{ll}\text { R/ Dispersi padat equivalen } 200 \mathrm{mg} \text { ibuprofen } & 300 \mathrm{mg} \\ \text { Selulosa mikrokristal } & 190 \mathrm{mg} \\ \text { Magnesii stearat } & 5 \mathrm{mg} \\ \text { Talkum } & 5 \mathrm{mg}\end{array}$

Timbang masing-masing bahan, lalu masukkan ke dalam lesung dan aduk rata. Campuran homogen dicetak langsung pada tablet press. Dengan bobot setiap tablet $500 \mathrm{mg}$

\section{Penetapan Kadar Zat berkhasiat}

Timbang 20 tablet dengan hati-hati dan hancurkan menjadi bubuk. Timbang 50 mg ibuprofen dari bubuk, masukkan ke dalam labu ukur 100ml, dan larutkan sampai tanda dengan $\mathrm{NaOH} \quad 0,1 \mathrm{~N}$. Kemudian saring larutan tersebut, buang beberapa tetes filtrat pertama dan kumpulkan filtrat berikutnya. Ambil 11,5 $\mathrm{ml}$ dari larutan ini ke dalam labu ukur 25 ml dan tambahkan $0,1 \mathrm{~N} \mathrm{NaOH}$ sampai tanda. Selain itu, diukur pada panjang gelombang maksimum dengan spektrofotometri ultraviolet. Tingkat ibuprofen yang dihitung.

Menurut Farmakope Indonesia edisi keempat, zat gizi yang terkandung dalam tablet ibuprofen tidak boleh kurang dari 90,0\% dari jumlah yang tercantum pada etiket dan tidak lebih dari 110,0\%.

\section{Absorpsi secara In Situ dalam Usus Halus Tikus \\ Pembedahan}

Anestesi dan pembedahan dilakukan sesuai dengan metode perfusi usus ortotopik yang telah divalidasi sebelumnya pada tikus (Fagerholm et al., 1996). Tikus dipuasakan selama 18 jam sebelum percobaan perfusi, tetapi air minum diperbolehkan. Ketamin dengan dosis $50 \mathrm{mg} / \mathrm{kg}$ BB digunakan untuk anestesi intraperitoneal.

\section{Pengujian Absorpsi Secara In Situ Teknik Perfusi Single Pass}

Cara kerja Pengujian Absorpsi secara in situ dengan teknik perfusi single pass sebagai berikut:

1) Anestesi mencit dengan injeksi intraperitoneal. 
2) Sesudah dibius, letakkan tikus terlentang di atas sepotong kayu berukuran 20 x $30 \mathrm{~cm}$. Empat kaki tikus diikat ke satu sisi kayu dengan wol. Mencit kemudian ditempatkan dalam waterbath listrik dengan suhu $37^{\circ} \mathrm{C}$.

3) Kemudian, buka rongga perut tikus dengan instrumen bedah.

4) Sesudah dibuka, ukur usus dari bagian bawah perut, lalu buat lubang $\pm 3 \mathrm{~cm}$ di bagian bawah perut untuk menempatkan kanula pertama. Ukur segmen duodenum dengan benang $10 \mathrm{~cm}$ dari ujung kanula pertama, lalu buat lubang untuk memasukkan kanula kedua.

5) Kanula pertama terhubung ke tabung infus melalui perangkat tiga arah, yang terhubung ke kantong infus yang berfungsi sebagai larutan natrium klorida fisiologis, buffer fosfat isotonik $\mathrm{pH}$ 5,9 dan larutan obat yang akan diperiksa.

6) Bersihkan usus halus dengan mengalirkan larutan $\mathrm{NaCl}$ fisiologis dengan kecepatan 0, 5 $\mathrm{ml} /$ menit untuk menghilangkan kotoran yang ada di usus halus yang dikenal dari larutan yang dikumpulkan dari kanula kedua.

7) Setelah itu ganti larutan $\mathrm{NaCl}$ fisiologis dengan larutan dapar fosfat isotonik $\mathrm{pH}$ 5,9 dan mengalir dengan kecepatan yang sama seperti di atas. Hentikan aliran setelah 30 menit. Selain itu, larutan dapar fosfat $\mathrm{pH} \quad 5,9$ isotonik dengan larutan 1 mmol ibuprofen dalam larutan dapar fosfat $\mathrm{pH}$ 5,9 isotonik.

8) Biarkan larutan sampel mengalami refluks selama 90 menit. Waktu pengambilan sampel adalah 10, 20, 30, 45, 60, dan 90 menit, dan volume sampel yang diambil adalah $1 \mathrm{ml}$.

9) Jumlah ibuprofen yang tidak terserap ditentukan dengan spektrofotometri UV pada panjang gelombang 225,5 nm. Selain itu, tingkat penyerapan ibuprofen dihitung.

10) Ulangi percobaan di atas untuk tablet ibuprofen padat terdispersi dan obat generik.

\section{HASIL DAN PEMBAHASAN}

Hasil dari data konsentrasi serapan adalah: konsentrasi awal-konsentrasi tidak terserap. Konsentrasi ibuprofen dihitung menggunakan persamaan regresi dari kurva kalibrasi duodenum tikus jantan dalam buffer fosfat $\mathrm{pH}$ 5,9 isotonik. 


$$
\mathrm{Y}=0,0447 \mathrm{x}+0,0102
$$

Sebagai contoh: Pada waktu $\mathrm{t}=10$ menit, dipipet larutan ibuprofen dari sediaan bahan baku sebanyak $1 \mathrm{ml}$, encerkan dengan larutan dapar fosfat isotonik pH 5,9 ke dalam labu ukur $10 \mathrm{ml}$ sampai garis tanda. Penyerapan kemudian diukur pada panjang gelombang 225,5 nm sehingga diperoleh absorbansi 0,5870, maka konsentrasi cuplikan pada menit ke 10 adalah:

$0,5870-0,0102 / 0,0447 \times 10 \mathrm{ml} / 1 \mathrm{ml}=129,0380 \mathrm{mcg} / \mathrm{ml}$ (konsentrasi yang tidak terabsorbsi)

Untuk memperoleh konsentrasi yang diabsorbsi dikurangi dengan konsentrasi awal yaitu:

$$
0,9977 \mathrm{mmol}=205,8000 \mathrm{mcg} / \mathrm{ml} \text {. }
$$

Maka konsentrasi yang diabsorbsi adalah:

$$
205,8000 \mathrm{mcg} / \mathrm{ml}-129,0380 \mathrm{mcg} / \mathrm{ml}=76,7620 \mathrm{mcg} / \mathrm{ml}
$$

Untuk perhitungan konsentrasi ibuprofen dari ibuprofen yang lain, Yaitu, tablet terdispersi padat dan tablet generik dilakukan dengan cara yang sama.

Informasi hasil kalkulasi diuji memakai program SPSS 16.00 ANOVA dan signifikan $(p<0,05)$, setelah itu dilanjutkan percobaan Duncan buat mengenali perbandingan antar perlakuan.

\section{Penetapan Kadar Tablet Ibuprofen dalam dispersi padat}

Menurut hasil penelitian, kandungan ibuprofen dalam formulasi tablet terdispersi padat masih memenuhi persyaratan Farmakope Indonesia versi IV yaitu $100,54 \% \pm 0,47$.

\section{Pengujian Absorbsi Secara In Situ Teknik Perfusi Single Pass}

Hasil uji Ibuprofen yang tidak terabsorbsi (Tabel I) perfusi single-pass insitu dari sistem dispersi padat tablet ibuprofen, tablet generik dan bahan baku ibuprofen dapat ditunjukkan pada Gambar I 
Tabel I. Data uji konsentrasi tak terabsorbsi ibuprofen, tablet terdispersi padat dan obat generik in situ pada duodenum tikus jantan Wistar

\begin{tabular}{|c|c|c|c|c|c|c|c|c|c|c|}
\hline \multirow[t]{2}{*}{$\begin{array}{c}\text { Nama } \\
\text { Sediaan }\end{array}$} & \multirow[t]{2}{*}{$\begin{array}{l}\text { Waktu } \\
\text { (menit) }\end{array}$} & \multicolumn{6}{|c|}{$\begin{array}{c}\text { Konsentrasi } \\
(\mathrm{mcg} / \mathrm{ml})\end{array}$} & \multirow[t]{2}{*}{ Jumlah } & \multirow[t]{2}{*}{$\begin{array}{l}\text { Rata } \\
\text { rata }\end{array}$} & \multirow[t]{2}{*}{$\begin{array}{l}\text { Standar } \\
\text { Deviasi }\end{array}$} \\
\hline & & I & II & III & IV & $\mathbf{V}$ & VI & & & \\
\hline \multirow{6}{*}{ Ibuprofen } & 10 & 129,0380 & 135,2796 & 121,9687 & 114,6532 & 140,8725 & 109,9776 & 751,7896 & 125,2983 & 11,9607 \\
\hline & 20 & 96,7114 & 113,1320 & 91,8395 & 95,1902 & 135,2796 & 89,9776 & 622,1253 & 103,6876 & 17,5305 \\
\hline & 30 & 81,6555 & 90,1119 & 82,6846 & 85,0559 & 110,9400 & 83,5123 & 533,9602 & 88,9934 & 11,1543 \\
\hline & 45 & 41,1186 & 65,2575 & 37,4500 & 43,8926 & 95,7494 & 34,9217 & 318,3898 & 53,0650 & 23,5392 \\
\hline & 60 & 32,9978 & 66,1298 & 32,0805 & 42,8635 & 72,8412 & 31,1633 & 278,0761 & 46,3460 & 18,5349 \\
\hline & 90 & 33,8031 & 54,0716 & 29,9105 & 40,8277 & 67,4944 & 29,0157 & 255,1230 & 42,5205 & 15,3452 \\
\hline \multirow{6}{*}{$\begin{array}{c}\text { Tablet } \\
\text { Dispersi } \\
\text { Padat }\end{array}$} & 10 & 92,3490 & 94,4965 & 102,6398 & 105,5928 & 108,1879 & 111,2304 & 614,4964 & 102,4161 & 7,5527 \\
\hline & 20 & 84,5414 & 86,0179 & 88,0089 & 87,3154 & 89,1499 & 105,6152 & 540,6487 & 90,1081 & 7,7629 \\
\hline & 30 & 63,3781 & 78,3445 & 72,7517 & 79,5973 & 79,7763 & 93,0425 & 466,8904 & 77,8151 & 9,7287 \\
\hline & 45 & 26,2192 & 29,6197 & 30,5817 & 36,0850 & 35,8389 & 52,8859 & 211,2304 & 35,2051 & 9,4563 \\
\hline & 60 & 24,2058 & 28,9262 & 29,2617 & 31,2975 & 32,5727 & 50,2685 & 196,5234 & 32,7554 & 9,0425 \\
\hline & 90 & 21,4541 & 27,0917 & 26,5772 & 29,2617 & 33,8479 & 45,5705 & 183,8031 & 30,6339 & 8,3497 \\
\hline \multirow{6}{*}{$\begin{array}{r}\text { Tablet } \\
\text { Generik }\end{array}$} & 10 & 125,1454 & 127,0694 & 127,2931 & 109,9553 & 116,3535 & 123,9150 & 729,7317 & 121,6220 & 6,9768 \\
\hline & 20 & 119,4407 & 107,6734 & 124,0045 & 104,8546 & 112,0805 & 110,9172 & 678,9709 & 113,1618 & 7,2433 \\
\hline & 30 & 80,2461 & 86,9575 & 88,2988 & 85,5928 & 84,8550 & 90,6264 & 516,5776 & 86,0963 & 3,5253 \\
\hline & 45 & 59,7987 & 68,9709 & 63,5570 & 41,7226 & 59,8658 & 70,3803 & 364,2953 & 60,7159 & 10,3143 \\
\hline & 60 & 51,5660 & 57,9642 & 62,1029 & 39,1946 & 49,2841 & 50,9172 & 311,0290 & 51,8382 & 7,8765 \\
\hline & 90 & 44,8546 & 57,4497 & 44,7651 & 39,3776 & 20,1342 & 49,0828 & 285,6600 & 47,6100 & 6,1463 \\
\hline
\end{tabular}

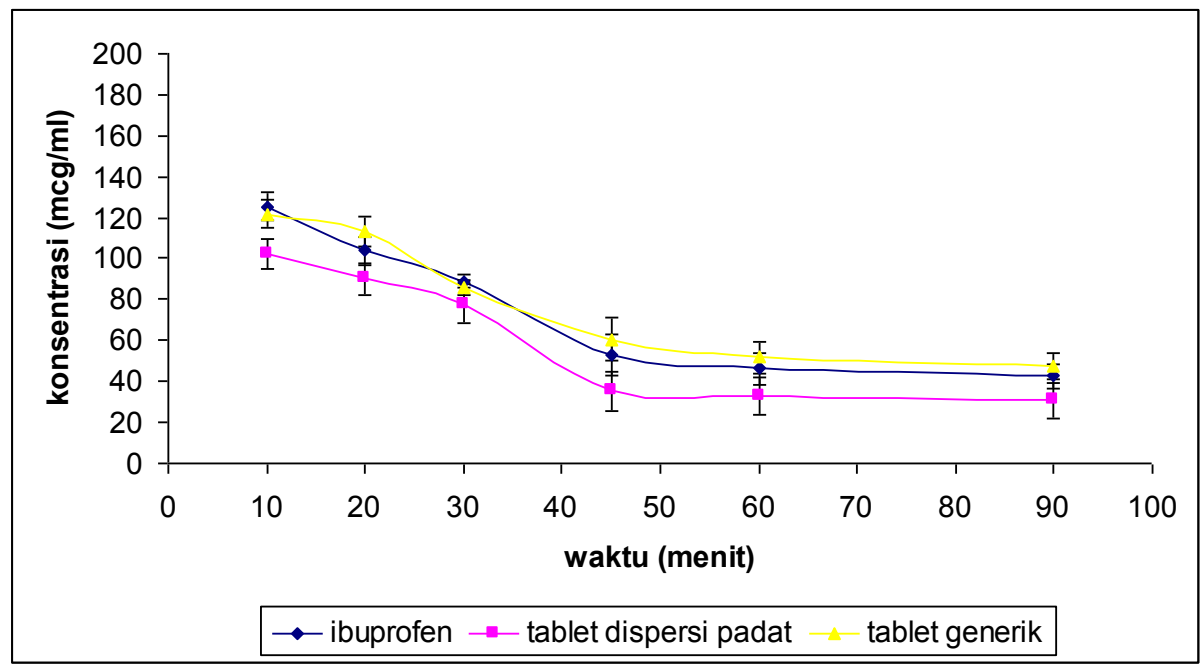

Gambar I . Grafik ibuprofen yang tidak terabsorpsi

Sedangkan hasil uji iburofen baku ibuprofen dapat ditunjukkan pada yang terabsorbsi (tabel II) dari tablet gambar II dispersi padat, tablet generik dan bahan

Tabel 2. Data uji penyerapan in situ ibuprofen, tablet terdispersi padat dan obat generik di duodenum tikus jantan Wistar

\begin{tabular}{|c|c|c|c|c|c|c|c|c|c|c|}
\hline \multirow{2}{*}{$\begin{array}{l}\text { Nama } \\
\text { Sediaan }\end{array}$} & \multirow{2}{*}{$\begin{array}{l}\text { Waktu } \\
\text { (menit) }\end{array}$} & \multicolumn{6}{|c|}{$\begin{array}{l}\text { Konsentrasi } \\
(\mathrm{mgc} / \mathrm{ml})\end{array}$} & \multirow[t]{2}{*}{ Jumlah } & \multirow[t]{2}{*}{ Rata-rata } & \multirow{2}{*}{$\begin{array}{l}\text { Standar } \\
\text { Deviasi }\end{array}$} \\
\hline & & I & II & III & IV & $\mathrm{V}$ & VI & & & \\
\hline & 10 & 76,7620 & 70,5209 & 83,8313 & 91,1468 & 64,9275 & 95,8224 & 483,0109 & 80,5018 & 11,9606 \\
\hline & 20 & 109,0880 & 92,6680 & 113,9605 & 110,6098 & 70,5204 & 115,8224 & 612,6697 & 102,1116 & 17,5298 \\
\hline & 30 & 124,1445 & 115,6881 & 123,1154 & 120,7441 & 94,8600 & 122,2877 & 700,8398 & 116,8066 & 11,5430 \\
\hline
\end{tabular}




\begin{tabular}{|c|c|c|c|c|c|c|c|c|c|c|}
\hline Ibupro & 45 & 164,6814 & 140,5425 & 168,3500 & 161,9074 & 110,0506 & 170,8783 & 916,4102 & 152,7350 & 23,5392 \\
\hline \multirow[t]{3}{*}{ fen } & 60 & 172,8022 & 139,6702 & 173,7195 & 162,9365 & 132,9588 & 174,6367 & 956,7239 & 159,4540 & 18,5349 \\
\hline & 90 & 171,9969 & 151,7284 & 175,8895 & 164,9723 & 138,3056 & 176,7843 & 979,6770 & 163,2795 & 15,3452 \\
\hline & 10 & 113,4510 & 111,3035 & 103,1602 & 100,2072 & 97,6121 & 94,5696 & 620,3036 & 103,3839 & 7,5527 \\
\hline \multirow{7}{*}{$\begin{array}{l}\text { Tablet } \\
\text { Dispersi } \\
\text { Padat }\end{array}$} & 20 & 121,2586 & 119,7821 & 117,7911 & 118,4846 & 116,6501 & 100,1848 & 694,1513 & 115,6919 & 7,7629 \\
\hline & 30 & 142,4219 & 127,4555 & 133,0483 & 126,2027 & 126,0237 & 112,7575 & 767,909 & 127,9849 & 9,7287 \\
\hline & 45 & 179,5808 & 176,1803 & 175,2183 & 269,7150 & 170,4110 & 152,9141 & 1024,0195 & 170,6698 & 9,4529 \\
\hline & 60 & 181,5942 & 176,8738 & 176,5383 & 174,5025 & 173,2273 & 155,5315 & 1038,3133 & 173,0522 & 9,0427 \\
\hline & 90 & 184,3459 & 178,7083 & 179,2228 & 176,5383 & 171,2295 & 160,2295 & 1050,9965 & 175,1662 & 8,3497 \\
\hline & 10 & 80,6546 & 78,1306 & 78,5069 & 95,8447 & 89,4465 & 81,8850 & 504,4683 & 84,6781 & 7,0741 \\
\hline & 20 & 86,3593 & 98,1266 & 81,7955 & 100,9454 & 93,7195 & 94,8828 & 555,8291 & 92,6382 & 7,2433 \\
\hline \multirow{4}{*}{$\begin{array}{l}\text { Tablet } \\
\text { Generik }\end{array}$} & 30 & 125,5539 & 118,8425 & 117,5002 & 120,2072 & 120,9450 & 115,1736 & 718,2224 & 119,7037 & 3,5253 \\
\hline & 45 & 146,0013 & 136,8291 & 142,2430 & 164,8774 & 145,9342 & 135,4197 & 870,5047 & 145,0841 & 10,3143 \\
\hline & 60 & 154,2340 & 147,8358 & 143,6971 & 166,6054 & 156,5159 & 154,8828 & 923,7710 & 153,9618 & 7,8765 \\
\hline & 90 & 160,9454 & 148,3503 & 161,0349 & 166,4264 & 155,6658 & 156,7172 & 949,1400 & 158,1900 & 6,1463 \\
\hline
\end{tabular}

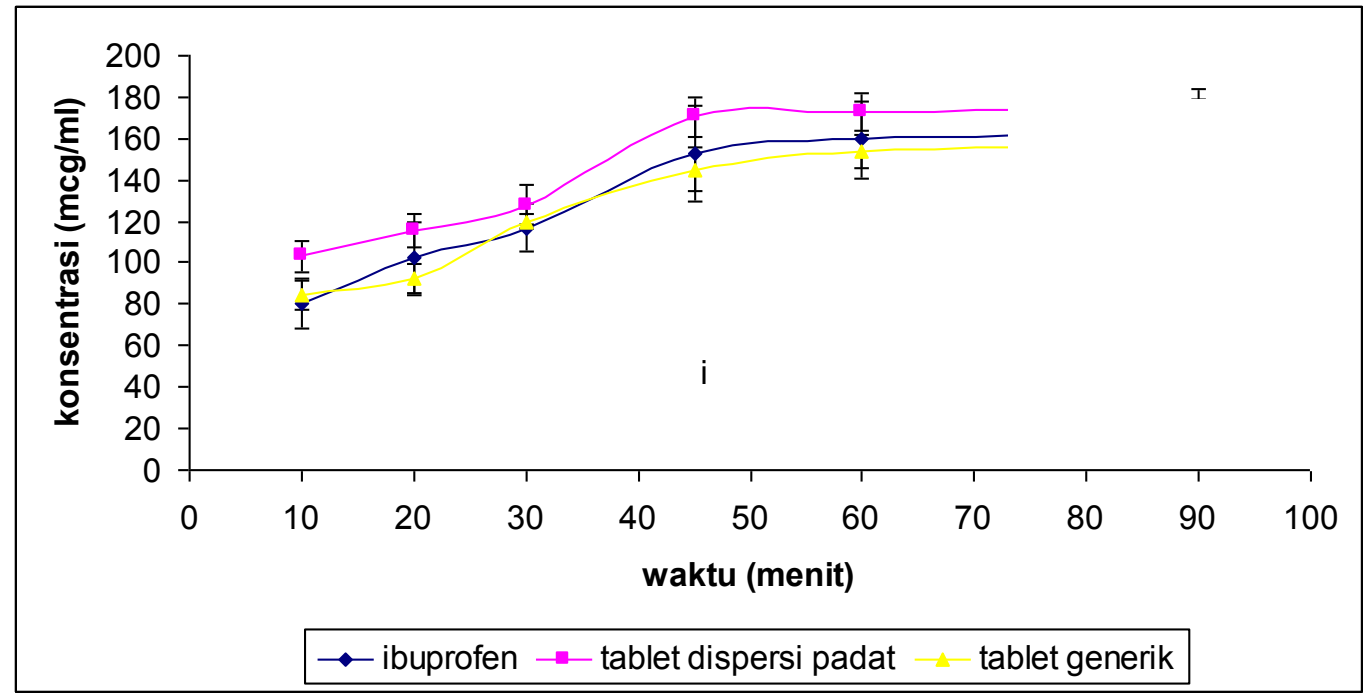

Gambar II. Grafik Ibuprofen yang Terabsorpsi

Dari hasil ini terlihat bahwa ibuprofen dari sediaan tablet dispersi padat lebih banyak terabsorbsi dibandingkan dengan sediaan tablet generik dan ibuprofen. Sementara ibuprofen yang terabsorbsi dari sediaan tablet generik berbeda-beda setiap waktu, kadang kadang menunjukkan lebih besar atau lebih kecil dari ibuprofen. Hal ini mungkin disebabkan tablet dispersi padat mengandung bahan tambahan yang berbeda dengan tablet generik. Tablet dispersi padat mengandung PEG 6000 yang dapat berinteraksi kompleks dengan obatobatan tertentu. Selain itu, akan mempengaruhi permeabilitas membran absorpsi (Karim, 2008; Florence dan Attwood, 1988).

Perbedaan ibuprofen yang terabsorbsi selain disebabkan oleh pembawa PEG 6000 kemungkinan juga dapat disebabkan oleh luas permukaan usus tempat absorbsi, Fluiditas atau saturasi usus dari sistem transportasi, yang dapat membatasi lewatnya 
membran (Shargel dan Yu, 2005; Aiache,1982).

generik pada menit ke 20,30, 45, 60

Hasil uji statistik ANOVA menunjukkan bahwa daya serap tablet terdispersi padat, ibuprofen dan obat

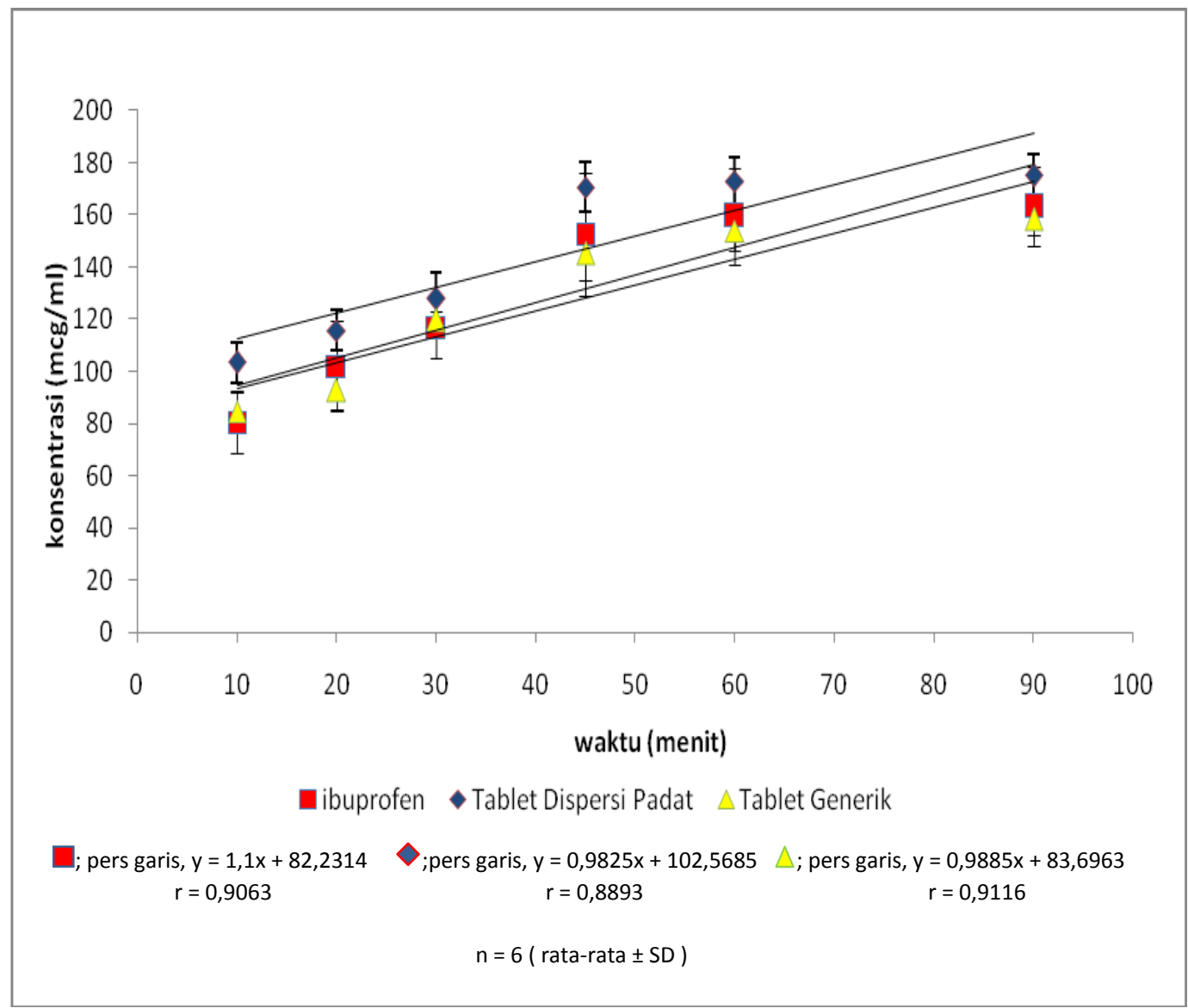

Gambar III. Grafik Ibuprofen Yang Terabsorbsi Dengan Persamaan Garis Linear

Dari grafik dapat dilihat, makin lama waktu yang diberikan konsenterasi ibuprofen yang terabsorbsi semakin meningkat. Demikian juga untuk ibuprofen dari stok tablet dispersi padat dan tablet generik. Hal ini menunjukkan mekanisme absorbsi dilakukan dengan cara linear. Nilai koefisien korelasi dan 90 tidak berbeda nyata $(\mathrm{p}>0,05)$. 


\section{KESIMPULAN}

Polietilen glikol 6000 mempunyai pengaruh terhadap absorbsi ibuprofen secara in situ, tetapi tidak menunjukkan perbedaan yang signifikan secara statistik ( $>00,05)$ pada menit ke 20,30, 45, 60 dan 90.

\section{UCAPAN TERIMAKASIH}

Pada kesempatan ini, peneliti ingin mengucapkan terima kasih kepada berbagai pihak yang telah membantu terwujudnya penelitian ini :

1. Direktur Poltekkes Kemenkes Medan

2. Ketua Pusat Penelitian dan

Pengabdian Masyarakat Poltekkes

Kemenkes Medan

3. Ketua Jurusan Farmasi Poltekkes

Kemenkes Medan

4. Tim Peneliti

\section{DAFTAR PUSTAKA}

Aiache, J.M. (1982). Farmasetika 2. Biofarmasi. Edisi Kedua. Penerjemah: Widji Soeratri. Surabaya: Penerbit Airlangga University Press. Hal. 8, 32-41, 153-154.

Ansel, C.H. (1989). Bentuk Sediaan Farmasi. Penerjemah: Farida Ibrahim. Cetakan Pertama. Edisi
IV. Penerbit UI Press. Jakarta: Hal. 112-115

Dahan, A.S., dan Amidon, G.L. (2009). Gastrointestinal Dissolution and Absorption of Class II Drugs. Metods and Principles in Medicinal Chesmistry. in: Mannhold, R., Kubinyi, H., dan R. Folkers. Drug Bioavailability. Estimation of Solubility, Permeability, Absorption and Bioavailability 2(40): 34-45

Ditjen POM ( 1995). Farmakope Indonesia. Edisi IV. Jakarta: Departemen Kesehatan R.I. Hal. 450-451, 1124, 1144, 1165, 1210

Fagerholm, U., Johansson, M., dan Lennernas, H. (1996). Comparison between Permeability Coefficients in Rat and Human Jejunum. Pharm. Res. 13: 1336-1342.

Florence, A.T., dan Attwood, D. (1988). Physicochemical Principles of Pharmacy. Edisi 2. New York: Published Chapman and Hall, Inc. Hal. 170-180, 283-290.

Gasniswara, G.S. (2007). Farmakologi dan Terapi. Edisi V. Universitas Indonesia Press: Jakarta. Hal. 5. 
Griffin, B.T., dan O’Driscoll, C.M. (2006). A Comparison of Intestinal Lymphatic Transport and Systemic Bioavailability of Saquinavir from Three LipidBased Formulation in the Anaesthetised Rad Model. $J$. Pharm. Pharmacol 58(3): 917925.

Leuner, C., dan Dressman, J. (2000). Improving Drug Solubility for Oral Delivery Using Solid Dispersion. Eur. J. Pharm. Biopharm. 50(3): 47-60.

Moffat, A.C., Osselton, M.D., dan Widdop, B. (2004). Clarke's Analysis of Drugs and Poisons. Edisi III. London: Pharmaceutical Press. Hal. 911

Newa, M., Bhandari, K.H., Kim, O.J., Im, S.J., Kim, J.A., Yoo, B.K., et al. (2008). Enhancement of Solubility, Dissolution and Bioavailability of Ibuprofen in Solid Dispersion Systems. Chem. Pharm. Bull. 56(4): 569574.

Shargel, L., dan Yu, A.B.C. (2005). Biofarmasetika and Farmakokinetika Terapan. Edisi II. Jakarta: Airlangga University Press. Hal. 86-95 